\title{
ANALISIS SENTIMEN BADAN PUSATSTATISTIK BERDASARKAN MEDIA ONLINE
}

\author{
Sentiment Analysis of Badan Pusat Statistik Based on Online Media
}

\author{
Rizki Adriansah¹, Ibnu Santoso ${ }^{2}$ \\ Politeknik Statistika STIS ${ }^{1}$ \\ Politeknik Statistika STIS ${ }^{2}$ \\ Jl. Sukarno Hatta No.86, Kp.Karang Raya Barat, Panjang, Bandarlampung \\ E-mail: 16.9395@stis.ac.id
}

\begin{abstract}
ABSTRAK
Ketersediaan informasi yang real-time untuk mengevaluasi hasil kerja yang dibuat oleh lembaga pemerintah masih minim adanya. Salah satunya adalah evaluasi terkait angka - angka statistik yang dikeluarkan oleh BPS. Untuk itu dibutuhkan suatu teknik yang dapat digunakan untuk menjawab permasalahan tersebut. Pemanfaatan berita dan menggabungkannya dengan teknologi dapat membantu mengatasi permasalahan gap waktu yang cukup jauh antara waktu publikasi dan pelaksanaan evaluasi yang ada. Berhasil terkumpul 1.410 berita, yang terdiri dari 699 berita di antaranya berasal dari detik.com, 323 berita berasal dari kompas.com serta 388 berita lainnya berasal dari tempo.co. Hasil sentiment analysis menunjukkan bahwa angka - angka statistik yang dikeluarkan BPS pada senarai rencana terbit BRS 2019 secara umum sudah cukup baik. Hasil penelitian menunjukkan bahwa berita dapat digunakan sebagai bahan analisis untuk melakukan penilaian terhadap publikasi angka - angka statistik yang dikeluarkan BPS dikarenakan hasilnya yang cukup relevan dengan keadaan aslinya.
\end{abstract}

Kata kunci: Berita, Analisis Sentimen, Badan Pusat Statistik

\section{ABSTRACT}

The availability of real-time information to evaluate policies made by the government is still minimal. One of them is the evaluation of statistical figures issued by BPS. For this we need a technique that can be used to answer these questions. The benefits of using and discussing with technology can help overcome the problem of a considerable gap in time between the time of publication and the implementation of existing evaluations. Successfully collected 1,410 news, consisting of 699 news collected from detik.com, 323 news collected from kompas.com and 388 other news collected from tempo.co. The result of sentiment analysis announced by BPS on the list of plans to be published by BRS 2019 is generally quite good. The results of the study indicate that news can be used as material for analysis to assess the publication of statistical figures issued by BPS estimating the results that are quite relevant to the original situation.

Keywords: News, Sentiment Analysis, Central Bureau of Statistics

\section{PENDAHULUAN}

Perkembangan internet yang pesat di Indonesia telah mendorong masyarakat untuk mengakses media online secara mudah melalui handphone atau gadget. Hasil survei yang dilakukan Asosiasi Penelitian Penyelenggara Jasa Internet Indonesia (APJII), menunjukkan bahwa selama tahun 2018, pengguna internet Indonesia tercatat sebanyak 171,17 juta, tumbuh sebesar 27,9 juta dari tahun sebelumnya 143,26 juta. Banyaknya pengguna internet ini yang kemudian akan membuka ruang publik bagi masyarakat, baik profesional atau amatir melakukan diseminasi informasi. Berbanding lurus dengan hal tersebut, meningkatnya pengguna internet yang terjadi akan dikuti semakin berkembangnya media online yang berada di Indonesia. Media online 
dijadikan sebagai wadah bagi masyarakat untuk menuliskan opini dan kritik terhadap berbagai aspek yang ada di Indonesia terutama terhadap kebijakan - kebijakan lembaga pemerintah baik lembaga pemerintah kementerian maupun lembaga pemerintah non kementerian. Salah satu lembaga pemerintah non kementerian yang ada di Indonesia adalah Badan Pusat Statistik (BPS).

BPS dalam praktiknya merupakan lembaga pemerintah yang memiliki fungsi untuk melakukan kegiatan statistik yang ditugaskan oleh pemerintah dalam berbagai macam bidang, seperti pertanian agraria, pertambangan, prindustrian, perhubungan, perdagangan, dll., sebagaimana tercantum dalam UU No.7 tahun 1960 pasal 2. Dalam selama kurun waktu tiap tahun BPS selalu mengeluarkan angka - angka statistik terkait keadaan yang ada di Indonesia. Hal ini tentunya akan menimbulkan reaksi di masyarakat terkait angka - angka yang di rilis oleh BPS tersebut. Reaksi tersebut berisi opini - opini masyarakat yang kemudian akan dituangkan dalam suatu media, baik media offline maupun online yang bersifat informal dalam bentuk rilis sebuah artikel berita . Penting untuk melihat dan menggali data dan informasi dari opini masyarakat tersebut terhadap angka - angka statistik yang di rilis sesuai yang ada pada senarai rencana terbit berita resmi statistik tahunan. Elfindri (2011) menawarkan metode prospektif sebagai salah satu metode yang dapat digunakan untuk menggali data dan informasi terkait opini masyarakat terhadap kegiatan atau program yang dilakukan oleh pemerintah.

Dalam Undan Undang Nomor 40 tahun 1999 tentang pers menyebutkan, "Pers nasional mempunyai fungsi sebagai media informasi, pendidikan, hiburan, dan kontrol sosial." Berdasarkan aturan tersebut dapat kita katakan bahwa media sosial dalam hal ini adalah media online dapat dimanfaatkan oleh BPS sebagai bahan untuk melihat prosfektif masyarakat terhadap rilis - rilis yang selalu dikeluarkan oleh BPS dalam senarai rencana terbit berita resmi statistik tahunan. Seperti yang telah dilakukan oleh Hidayat (2016) menggunakan media online dalam hal ini berita sebagai data untuk melakukan analisis pelayanan publik yang dilakukan selama selama seratus hari kepemimpinan Walikota Medan.

Saat ini, berita telah menjadi salah satu wadah bagi masyarakat untuk menuangkan opini perihal kinerja ataupun hasil dari suatu program dan kegiatan yang dilakukan lembaga pemerintah kementerian maupun lembaga pemerintah non kementerian. Tentunya BPS sebagai salah satu lembaga pemerintah non kementerian pun tak luput dari pemberitaan yang ada pada suatu media massa. Media massa dapat dijadikan sebagai suatu gambaran untuk menilai tanggapan masyarakat terhadap angka - angka statistik yang di rilis oleh BPS. Caranya dengan melakukan evaluasi terhadap pemberitaan terkait dengan angka - angka statistik tersebut, yang dalam penelitian ini lebih terkhusus pada angka - angka statistik yang dirilis pada Senarai Rencana Terbit Berita Resmi Statisitik tahun 2019. Bentuk opini yang tertuang pada pemberitaan tersebut dapat dimanfaatkan oleh BPS untuk memberikan penjelasan lebih lanjut jika terdapat banyak sentimen negatif yang muncul pada pemberitaan terkait angka - angka statistik yang telah di rilis oleh BPS sebelumnya.

Evaluasi yang diakukan terhadap pemberitaan yang ada terkait angka - angka statistik yang di rilis BPS masih dilkukan secara konvensional. Evaluasi yang dilakukan dengan konvensional ini sering menimbulkan beberapa masalah, seperti adanya gap waktu yang cukup jauh antara waktu publikasi dan pelaksanaan evaluasi yang ada. Kemudian permasalahan atas gap waktu yang jauh ini akan diikuti oleh permasalahan lain yaitu kurang relevan lagi hasil evaluasi dengan kondisi pada waktu hasil evaluasi selesai. Atas dasar hal tersebut, peneliti mencoba untuk memanfaatkan berita sebagai data analisis serta penilaian terkait angka - angka yang dirilis oleh BPS berdasarkan Senarai Rencana Terbit Berita Resmi Statistik Tahun 2019. Peneliti melakukan penilaian terhadap opini masyarakat terhadap angka - angka statistik tersebut. Adapun sumber data yang dalam hal ini adalah berita online dikumpulkan dari beberapa sumber seperti Detik, Kompas, dan Tempo. Berita tersebut yang telah dikelompokkan berdasarkan rilis yang ada akan dilakukan analisis lebih lanjut untuk dilihat bagaimana sentimen yang ada pada setiap angka - angka yang di rilis BPS dalam Senarai Rencana Terbit, apakah bernilai positif, negatif ataupun netral. Dilihat juga siapa saja tokoh yang sering dibahas dalam berita tersebut menggunakan model Named Entity Recognition. 


\section{METODE}

Penelitian ini menggunakan berita sebagai bahan analisisnya. Berita dikumpulkan dari laman berita detik.com, kompas.com dan tempo.co. Berita dikumpulkan menggunakan aplikasi Kapow dengan periode penerbitan berita pada tahun 2019. Berita yang dikumpulkan merupakan berita yang hanya bersesuaian dengan poin - poin pada senarai rencana terbit berita resmi statistik (BRS) tahun 2019. Data yang digunakan untuk keperluan analisis adalah berita yang di-crawling menggunakan robot yang dibuat menggunakan Kapow. Sebelumnya dilakukan proses instalasi Kapow terlebih dahulu pada komputer peneliti. Kemudian memulai Kapow dengan membuka Start Management Console hingga terbuka jendela RoboServer. Selanjutnya yakni mengisi lisensi Kapow. Lisensi yang digunakan peneliti merupakan lisensi resmi yang berasal dari Badan Pusat Statistik (BPS). Setelah itu peneliti mendesain robot Kapow di Design Studio 9.6.2.

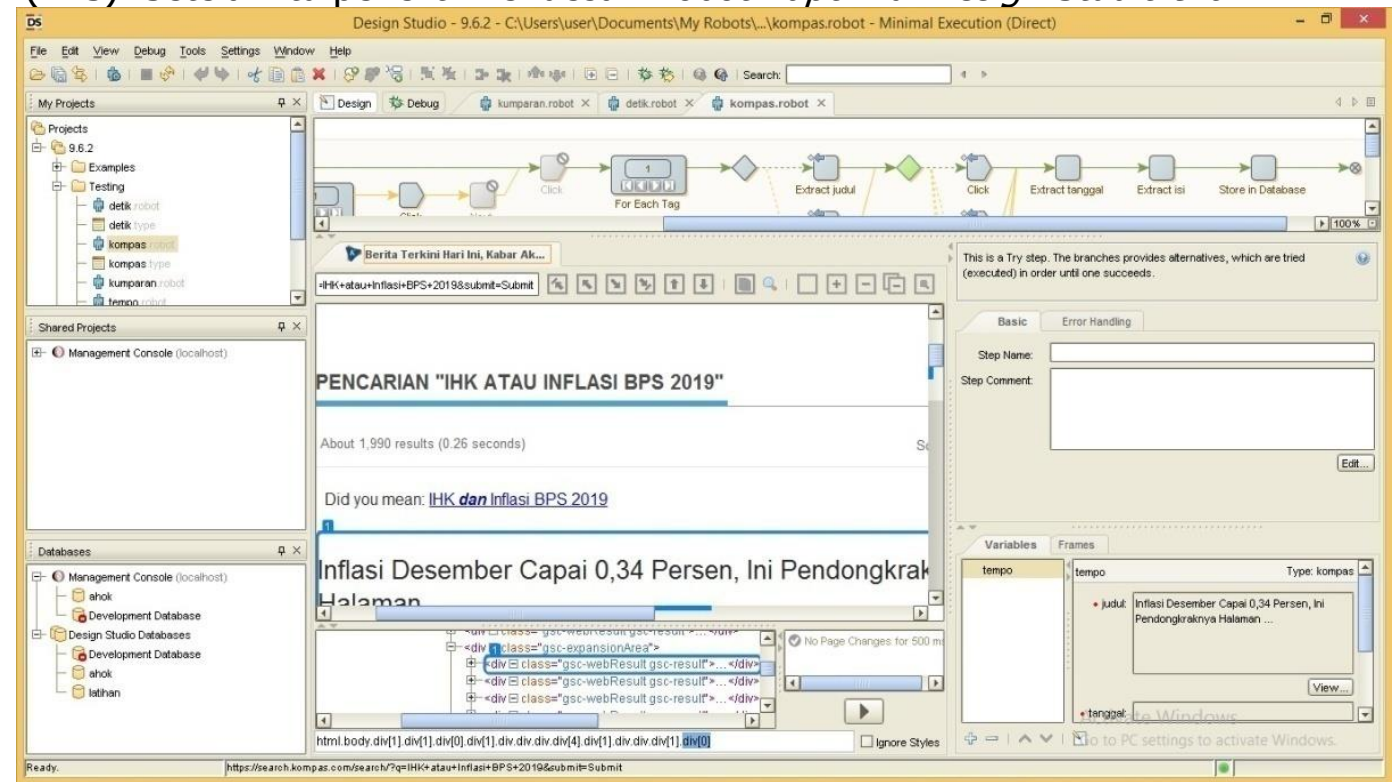

Gambar 1. Design Studio 9.6.2 Kofax Kapow

Langkah selanjutnya yaitu dilakukan konfigurasi terhadap database agar data hasil crawling dapat disimpan langsung dalam database. Setiap website berita dibuatkan satu robot, karena setiap robot hanya dapat digunakan untuk satu website saja. Berikut merupakan salah satu contoh hasil crawling yang telah berhasil tersimpan pada database.

\begin{tabular}{|c|c|c|c|c|c|}
\hline & & & RobotName & FirstExtracted & LastExtracted \\
\hline $\begin{array}{l}\text { Perintah Jokowi ke Ahok: Bereskan TPPI } \\
\text { Kurang dari... }\end{array}$ & $\begin{array}{l}\text { Kompas.com - 22/12/2019, } \\
\text { 20:00 WIB }\end{array}$ & $\begin{array}{l}\text { JAKARTA, KOMPAS.com - Dalam kunjungan } \\
\text { kerjanya ke... }\end{array}$ & tempo & 2020-01-17 12:54:19 & $2020-01-1712: 54: 19$ \\
\hline $\begin{array}{l}\text { Kembangkan Mesin Domestik Halaman all - } \\
\text { Kompas.com }\end{array}$ & $\begin{array}{l}\text { Kompas com - 24/05/2013, } \\
\text { 11:22 WIB }\end{array}$ & $\begin{array}{l}\text { JAKARTA, KOMPAS com - Kementerian } \\
\text { Perindustrian } t . .\end{array}$ & tempo & $2020-01-17$ 07:57:34 & $2020-01-1708: 02: 21$ \\
\hline $\begin{array}{l}\text { Cabai Merah dan Tiket Transpotasi } \\
\text { Dongkrak Inflasi... }\end{array}$ & $\begin{array}{l}\text { Kompas.com - 10/06/2019, } \\
\text { 12:16 WIB }\end{array}$ & $\begin{array}{l}\text { JAKARTA, KOMPAS.com - Badan Pusat } \\
\text { Statistik (BPS)... }\end{array}$ & tempo & $2020-01-2011: 47: 45$ & $2020-01-2014: 23: 08$ \\
\hline $\begin{array}{l}\text { Ekonomi Indonesia Hanya Dikuasai oleh } 20 \\
\text { Persen Pe... }\end{array}$ & $\begin{array}{l}\text { Kompas com - 06/04/2016, } \\
15: 55 \text { WIB }\end{array}$ & $\begin{array}{l}\text { JAKARTA, KOMPAS .com - Perekonomian } \\
\text { Indonesia hanya... }\end{array}$ & tempo & $2020-01-2100: 44: 53$ & $2020-01-21 \quad 04: 24: 50$ \\
\hline $\begin{array}{l}\text { Kemenkeu Luncurkan Aplikasi INSWMobile } \\
\text { Fasilitasi ... }\end{array}$ & $\begin{array}{l}\text { Kompas.com - 15/01/2020, } \\
\text { 13:46 WIB }\end{array}$ & $\begin{array}{l}\text { JAKARTA, KOMPAS.com - Kementerian } \\
\text { Keuangan melalui... }\end{array}$ & tempo & $2020-01-16$ 18:48:49 & $2020-01-16 \quad 18: 50: 39$ \\
\hline $\begin{array}{l}\text { Suku Bunga BI Terus Dipangkas, Kok Bunga } \\
\text { Kredit Dk... }\end{array}$ & $\begin{array}{l}\text { Kompas.com - 24/10/2019, } \\
\text { 17.41 WIB }\end{array}$ & $\begin{array}{l}\text { JAKARTA, KOMPAS com - Bank Indonesia (BI) } \\
\text { telah me... }\end{array}$ & tempo & $2020-01-1709: 35: 32$ & $2020-01-17 \quad 13: 00: 52$ \\
\hline $\begin{array}{l}\text { Raksasa Tekstil Indonesia Ini Akhirnya Buka } \\
\text { Suara ... }\end{array}$ & $\begin{array}{l}\text { Kompas.com - 10/08/2019, } \\
\text { 10:39 WIB }\end{array}$ & $\begin{array}{l}\text { JAKARTA, KOMPAS.com - Duniatex Group } \\
\text { akhirnya memb... }\end{array}$ & tempo & $2020-01-1709: 40: 38$ & $2020-01-17$ 13:09:00 \\
\hline $\begin{array}{l}\text { Pertumbuhan Ekonomi } 2015 \text { Terendah } \\
\text { dalam Enam Tahun... }\end{array}$ & $\begin{array}{l}\text { Kompas com - 07/02/2016, } \\
18: 28 \text { WIB }\end{array}$ & $\begin{array}{l}\text { JAKARTA, KOMPAS. com - Pertumbuhan } \\
\text { ekonomi Indonesi... }\end{array}$ & tempo & $2020-01-1620: 46-12$ & $2020-01-1620: 46: 12$ \\
\hline $\begin{array}{l}\text { Indonesia Masuk } 10 \text { Besar Negara Industri } \\
\text { Manufaktu... }\end{array}$ & $\begin{array}{l}\text { Kompas.com - 13/06/2017, } \\
06: 07 \text { WIB }\end{array}$ & $\begin{array}{l}\text { JAKARTA, KOMPAS.com - Menteri } \\
\text { Perindustrian ( Menp... }\end{array}$ & tempo & $2020-01-17$ 07:05:53 & $2020-01-1708: 02: 08$ \\
\hline $\begin{array}{l}\text { Jumlah Orang Miskin Bertambah tapi } \\
\text { Ketimpangan Sta... }\end{array}$ & $\begin{array}{l}\text { Kompas.com - 17/07/2017, } \\
\text { 13:17 WIB }\end{array}$ & $\begin{array}{l}\text { JAKARTA, KOMPAS . com - Badan Pusat } \\
\text { Statistik (BPS)... }\end{array}$ & tempo & $2020-01-21$ 03:32:42 & $2020-01-21 \quad 03: 38: 05$ \\
\hline $\begin{array}{l}\text { BCA Beri Kuliah Umum Perkembangan } \\
\text { Teknologi Inform... }\end{array}$ & $\begin{array}{l}\text { Kompas.com - 16/03/2018, } \\
\text { 13:42 WIB }\end{array}$ & $\begin{array}{l}\text { BANDUNG, KOMPAS com - PT Bank Central } \\
\text { Asia Tbk ( B... }\end{array}$ & tempo & $2020-01-2104: 41: 36$ & $2020-01-2104: 49: 16$ \\
\hline $\begin{array}{l}\text { Startup eFishery Hadirkan Kampung } \\
\text { Perikanan Digita... }\end{array}$ & $\begin{array}{l}\text { Kompas com - 05/12/2019, } \\
15: 50 \text { WIB }\end{array}$ & $\begin{array}{l}\text { JAKARTA, KOMPAS com - Perusahaan rintisan } \\
\text { ( startu.. }\end{array}$ & tempo & $2020-01-16 \quad 17: 28: 00$ & $2020-01-16 \quad 17: 28: 00$ \\
\hline $\begin{array}{l}\text { Harga Daging dan Beras Melambung, } \\
\text { Kepala BPS Yakin... }\end{array}$ & $\begin{array}{l}\text { Kompas.com - 21/07/2014, } \\
\text { 13:23 WIB }\end{array}$ & $\begin{array}{l}\text { JAKARTA, KOMPAS.com - Kepala Badan Pusat } \\
\text { Statistik... }\end{array}$ & tempo & $2020-01-1708: 57: 4$ & $2020-01-1708: 57: 47$ \\
\hline $\begin{array}{l}\text { Surplus dengan AS, Neraca Perdagangan } \\
\text { RI Masih Def.. }\end{array}$ & $\begin{array}{l}\text { Kompas.com - 24/06/2019, } \\
\text { 17:27 WIB }\end{array}$ & $\begin{array}{l}\text { JAKARTA, KOMPAS com - Badan Pusat } \\
\text { Statistik (BPS) ... }\end{array}$ & tempo & $2020-01-15 \quad 14: 46: 16$ & $2020-01-17 \quad 15: 04: 59$ \\
\hline
\end{tabular}

Gambar 2. Database berita hasil crawling

Metode analisis yang digunakan pada penelitian ini yakni analisis deskriptif dan content based analysis. Analisis deskriptif yang digunakan untuk melihat gambaran umum mengenai data yang dimiliki sehingga informasi yang terkandung dapat ditangkap oleh pembaca dengan baik. Content based analysis digunakan untuk melihat secara mendalam mengenai informasi yang terdapat pada berita, termasuk fenomena sosial yang sering diberitakan. 
Sebelum menghasilkan nilai sentimen baik untuk tiap berita maupun opini dalam berita, dilakukan tahapan pre-processing terlebih dahulu. Dalam tahapan pre-processing dilakukan aktifitas seperti pemisahan kata, penghapusan simbol, pengubahan kata menjadi huruf kecil dan penghapusan stopword. Data yang sudah bersih kemudian dilakukan pengecekan apakah kata dalam data yang sudah bersih terdapat dalam kamus kata positif dan negatif atau tidak, sebagaimana yang dilakukan oleh Wahid \& Azhari (2016) serta Liu, Hu \& Cheng (2005). Setelah itu data dihitung jumlah kata positif dan negatifnya untuk mendapatkan nilai sentimennya. Untuk memperoleh informasi mengenai tokoh, jabatan, dan lokasi dalam berita, kita menggunakan model Named Entity Recognition (NER) dengan bantuan library SpaCy.

\section{HASIL DAN PEMBAHASAN}

Terdapat 3 poin pada rilis Senarai Rencana Terbit Berita Resmi Statistik 2019 yang tidak memiliki satu pun artikel terkait dari hasil crawling pada 3 portal berita baik pada detik.com, kompas.com, maupun tempo.co yaitu poin nomor 11 tentang Indeks Harga Produsen, poin nomor 12 tentang Pola Distribusi Perdagangan Komoditas Strategis, dan poin nomor 19 tentang Indeks Kepuasan Jemaah Haji Indonesia (IKJHI) 1440H/2019M sehingga pada ketiga poin ini tidak dapat dilakukan sentimen analisisnya.

\begin{tabular}{|c|c|c|c|c|c|}
\hline \multirow{2}{*}{ No } & \multirow{2}{*}{ Poin dalam ARC } & \multicolumn{3}{|c|}{ Sentimen per Poin } & \multirow{2}{*}{ Total } \\
\hline & & Positif & Negatif & Netral & \\
\hline (1) & (2) & (3) & (4) & (5) & (6) \\
\hline 1 & $\begin{array}{c}\text { Perkembangan Indeks Harga } \\
\text { Konsumen/Inflasi }\end{array}$ & 107 & 86 & 79 & 272 \\
\hline 2 & $\begin{array}{c}\text { Perkembangan Ekspor dan } \\
\text { Impor Indonesia }\end{array}$ & 307 & 133 & 177 & 617 \\
\hline 3 & $\begin{array}{c}\text { Perkembangan Pariwisata dan } \\
\text { Transportasi }\end{array}$ & 49 & 10 & 24 & 83 \\
\hline 4 & $\begin{array}{c}\text { Perkembangan Nilai Tukar } \\
\text { Petani, Harga Gabah dan Beras }\end{array}$ & 31 & 9 & 14 & 54 \\
\hline 5 & $\begin{array}{c}\text { Pertumbuhan Ekonomi } \\
\text { Indonesia (Produk Domestik } \\
\text { Bruto) }\end{array}$ & 204 & 49 & 94 & 347 \\
\hline 6 & $\begin{array}{l}\text { Indeks Tendensi Bisnis dan } \\
\text { Indeks Tendensi Konsumen }\end{array}$ & 8 & 0 & 2 & 10 \\
\hline 7 & $\begin{array}{c}\text { Perkembangan Tenaga Kerja } \\
\text { Indonesia }\end{array}$ & 14 & 14 & 8 & 36 \\
\hline 8 & $\begin{array}{c}\text { Indeks Harga Perdagangan } \\
\text { Besar }\end{array}$ & 2 & 2 & 1 & 5 \\
\hline 9 & Profil Kemiskinan di Indonesia & 32 & 8 & 25 & 65 \\
\hline 10 & Indeks Perilaku Anti Korupsi & 5 & 2 & 3 & 0 \\
\hline 11 & Indeks Harga Produsen & 0 & 0 & 0 & 10 \\
\hline 12 & $\begin{array}{c}\text { Pola Distribusi Perdagangan } \\
\text { Komoditas Strategis }\end{array}$ & 0 & 0 & 0 & 0 \\
\hline 13 & Upah Buruh & 15 & 12 & 10 & 37 \\
\hline 14 & $\begin{array}{c}\text { Pertumbuhan Produksi Industri } \\
\text { Manufaktur }\end{array}$ & 15 & 4 & 6 & 25 \\
\hline 15 & Indeks Pembangunan Manusia & 28 & 6 & 8 & 42 \\
\hline 16 & Gini Rasio & 13 & 3 & 8 & 24 \\
\hline 17 & Indeks TIK & 1 & 0 & 0 & 1 \\
\hline 18 & Indeks Demokrasi Indonesia & 4 & 1 & 3 & 8 \\
\hline 19 & $\begin{array}{c}\text { Indeks Kepuasan Jemaah Haji } \\
\text { Indonesia (IKJHI) } \\
1440 \mathrm{H} / 2019 \mathrm{M} \\
\end{array}$ & 0 & 0 & 0 & 0 \\
\hline
\end{tabular}


Tabel 1. Hasil Sentimen

Pada tabel 1, sebanyak 39,3\% dari total 272 berita terkumpul yang membahas mengenai inflasi memiliki sentimen positif. Kemudian $31,6 \%$ memiliki sentimen negatif dan sisanya sebanyak 29.0\% memiliki sentimen netral. Kemudian jika kita mencoba melihat sentimen dalam setiap bulan seperti pada gambar 4, terlihat bahwa sentimen pada bulan maret, juli, dan desember didominasi oleh sentimen negatif. Dominasi sentimen negatif yang terjadi pada bulan maret sejalan dengan fakta bahwa terjadi deflasi pada bulan februari yang terpublikasi melalui BRS bulan maret tentang Indeks Harga Konsumen /Inflasi. Deflasi terjadi karena adanya penurunan harga yang ditunjukkan oleh turunnya beberapa indeks kelompok pengeluaran, yaitu kelompok bahan makanan sebesar 1,11 persen (BRS IHK/Inflasi Maret, 2019). Kemudian dominasi sentimen negatif pada bulan juni sejalan dengan fakta bahwa inflasi yang terjadi pada bulan mei yang mana kenaikan harga makanan pada bulan puasa menjadi penyumbang terbesar dalam inflasi yang terjadi. Selanjutnya dominasi sentimen negatif pada bulan desember sejalan dengan fakta bahwa tingkat inflasi tahun kalender (Januari-November) 2019 sebesar 2,37 persen dan masih jauh dibawah target sebesar 3,5 persen. Hal - hal tersebut turut berkontribusi menyebabkan sentimen berita bernilai negatif pada bulan maret, juni, dan desember.

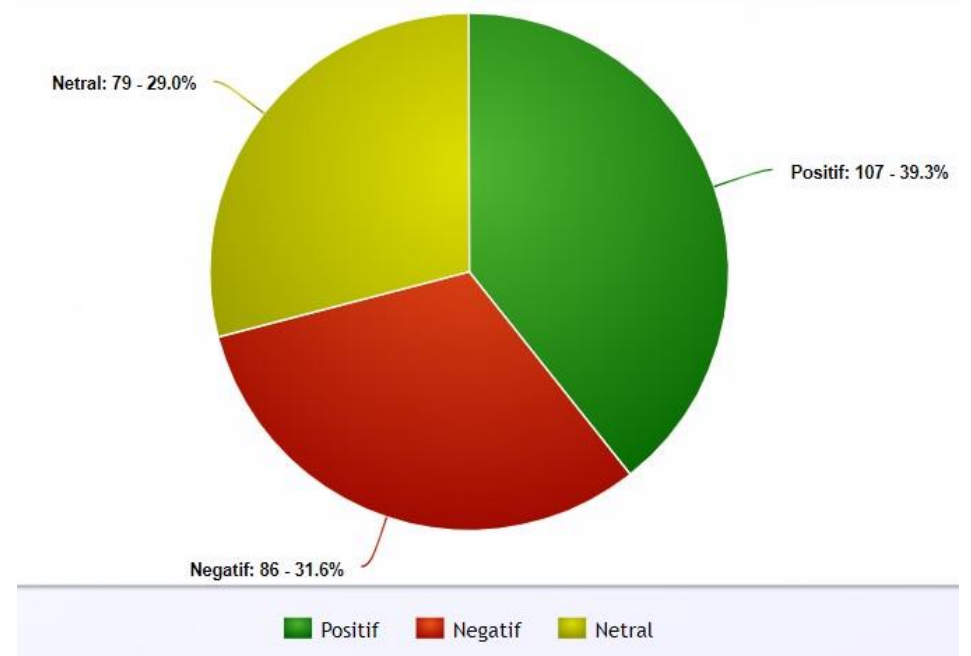

Gambar 3. Pie Chart sentiment terhadap inflasi

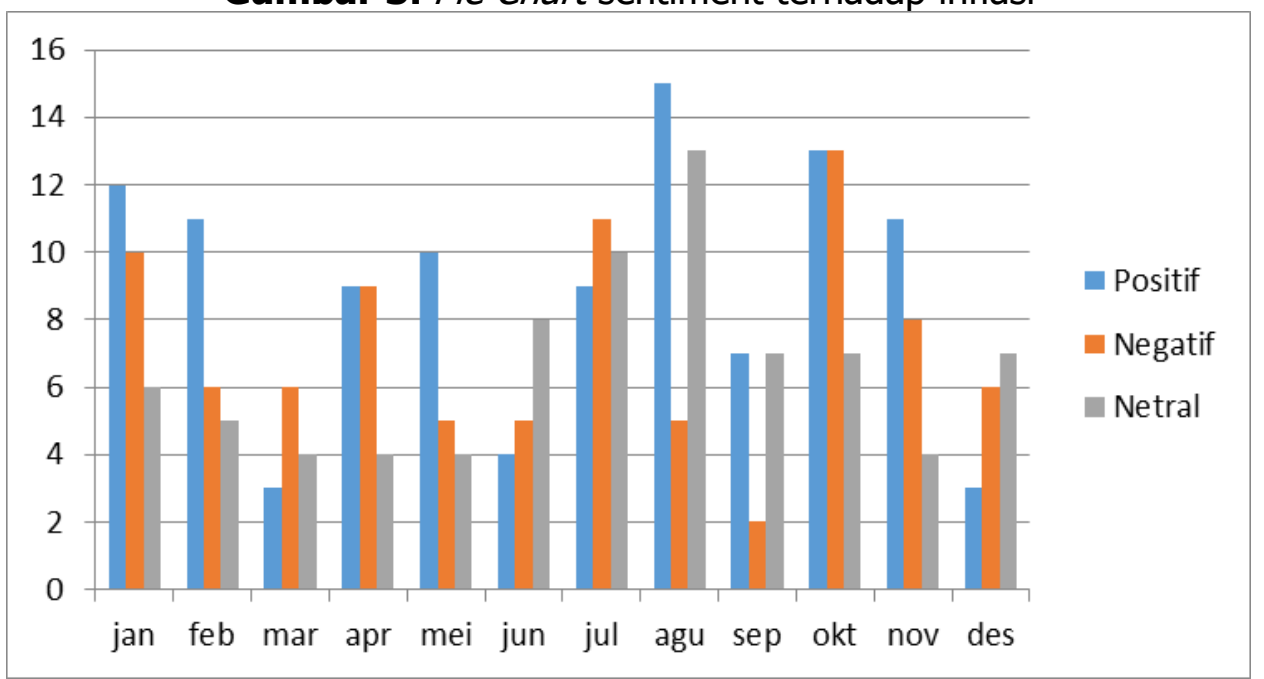

Gambar 4. Bar chart sentimen terhadap inflasi berdasarkan bulan

Pada tabel 1, sebanyak $49,8 \%$ dari total 617 berita terkumpul yang membahas mengenai ekspor dan impor memiliki sentimen positif. Kemudian $21,6 \%$ memiliki sentimen negatif dan sisanya sebanyak $28.7 \%$ memiliki sentimen netral. Neraca perdagangan Indonesia secara kumulatif pada januari-november tahun 2019 jika dibandingkan periode yang sama pada tahun 2018 mengalami perbaikan yang cukup signifikan, dari defisit $\$ 7,62$ juta dollar menjadi defisit $\$ 3,1$ juta dollar. Kemudian jika kita mencoba melihat sentimen dalam bulan, terlihat bahwa di setiap bulannya sentimen terhadap ekspor dan impor selalu bernilai positif. Jika kita melihat fakta pada neraca perdagangan dan mencoba membandingkan pada tahun sebelumnya untuk tiap bulannya, 
maka kita akan mendapati bahwa pada saat terjadi penurunan dalam neraca perdagangan tetapi tidak terlalu signifikan, dan ketika terjadi kenaikan, kenaikan tersebut cukup signifikan.

Pada tabel 1, sebanyak 59,0\% dari total 83 berita terkumpul yang membahas mengenai pariwisata dan transportasi memiliki sentimen positif. Kemudian 12,0\% memiliki sentimen negatif dan sisanya sebanyak $28.9 \%$ memiliki sentimen netral. Terobosan baru dalam perhitungan jumlah wisatawan mancanegara dengan menggunakan mobile positioning data (MPD) berkontribusi besar dalam menghasilkan sentimen berbobot positif. Arief yahya, Menteri Pariwisata (2014-2019) mengatakan bahwa dengan MPD, perhitungan jumlah wisatawan mancanegara akan lebih akurat, lebih mudah, lebih murah, dan tidak ada campur tangan manusia.

Pada tabel 1, sebanyak 57,4\% dari total 54 berita terkumpul yang membahas mengenai NTP, harga gabah dan beras memiliki sentimen positif. Kemudian 16,7\% memiliki sentimen negatif dan sisanya sebanyak $25.9 \%$ memiliki sentimen netral. Hasil sentimen yang didominasi dengan sentimen positif sejalan dengan fakta bahwa sepanjang tahun 2019 nilai NTP mengalami kenaikan jika dibandingkan dengan nilai NTP sepanjang 2018.

Pada tabel 1, sebanyak $58,8 \%$ dari total 347 berita terkumpul yang membahas mengenai Produk Domestik Bruto (PDB) memiliki sentimen positif. Kemudian 14,1\% memiliki sentimen negatif dan sisanya sebanyak $27,1 \%$ memiliki sentimen netral. Kemudian jika kita mencoba melihat sentimen dalam setiap triwulan, terlihat bahwa di setiap triwulannya sentimen terhadap ekspor dan impor selalu bernilai positif. Dominasi sentimen positif sejalam dengan fakta bahwa ekonomi Indonesia tumbuh sepanjang periode triwulan IV 2018 sampai triwulan III 2019 walau cenderung melambat tiap triwulannya (BRS PDB November, 2019).

Pada tabel 1, sebanyak $80,0 \%$ dari total 10 berita terkumpul yang membahas mengenai Indeks Tendensi Bisnis (ITB) dan Indeks Tendensi Konsumen (ITK) memiliki sentimen positif. Kemudian 20,0\% sisanya memiliki sentimen netral. Dominasi sentimen positif yang terjadi sejalan dengan fakta bahwa nilai ITB secara umum terus tumbuh dan nilai ITK secara umum menunjukkan bahwa konsumen merasakan peningkatan ekonomi pada tiap periode rilis yang ada pada tahun 2019 (BRS ITB-ITK November, 2019).

Pada tabel 1, sebanyak $38,9 \%$ dari total 36 berita terkumpul yang membahas mengenai tenaga kerja Indonesia memiliki sentimen positif. Kemudian 38,9\% memiliki sentimen negatif dan sisanya sebanyak 2,2\% memiliki sentimen netral. Berdasarkan persentase tersebut didapat bahwa jumlah artikel terkait tenaga kerja yang memiliki sentimen positif maupun negatif seimbang.

Pada tabel 1, sebanyak $40,0 \%$ dari total 5 berita terkumpul yang membahas mengenai Indeks Harga Perdagangan Besar memiliki sentimen positif. Kemudian 40,0\%\% memiliki sentimen negatif dan sisanya sebanyak 20,0\% memiliki sentimen netral. Berdasarkan persentase tersebut didapat bahwa jumlah artikel terkait upah buruh yang memiliki sentimen positif maupun negatif seimbang.

Pada tabel 1, sebanyak $49,2 \%$ dari total 65 berita terkumpul yang membahas mengenai profil kemiskinan Indonesia memiliki sentimen positif. Kemudian $12,3 \%$ memiliki sentimen negatif dan sisanya sebanyak $38.5 \%$ memiliki sentimen netral. Dominasi sentimen positif yang terjadi sejalan dengan fakta bahwa persentase penduduk miskin mengalami penurunan sebanyak 0,25\% pada periode Maret 2019 menjadi 9,41\% yang sebelumnya pada September 2018 sebesar 9,66\% (BRS Profil Kemiskinan Juli, 2019).

Pada tabel 1, sebanyak $44,4 \%$ dari total 9 yang membahas mengenai Indeks Perilaku Anti Korupsi (IPAK) memiliki sentimen positif. Kemudian 55,6\% memiliki sentimen netral. Untuk poin tentang IPAK, sentimen didominasi oleh sentimen netral, kemudian positif dan tidak ada artikel yang memiliki sentimen negatif terkait IPAK. Hal tersebut sejalan dengan fakta bahwa IPAK Indonesia pada tahun 2019 mengalami kenaikan menjadi 3,70 terhadap IPAK Indonesia pada tahun 2018 yang bernilai 3,66 ((BRS IPAK September, 2019).

Pada tabel 1, sebanyak $40,5 \%$ dari total 37 berita terkumpul yang membahas mengenai upah buruh memiliki sentimen positif. Kemudian 32,4\% memiliki sentimen negatif dan sisanya sebanyak $27.0 \%$ memiliki sentimen netral. Berdasarkan persentase tersebut didapat bahwa jumlah artikel terkait upah buruh yang memiliki sentimen positif maupun negatif cukup seimbang. Hal ini sejalan dengan fakta bahwa sepanjang tahun 2019 angka statistik yang di rilis terkait upah buruh yaitu angka perkembangan upah nominal buruh tani maupun bangunan mengalami kenaikan 
sepanjang tahun 2019 sedangkan untuk untuk angka perkembangan upah riil buruh tani maupun bangunan terjadi fluktuatif sepanjang tahun dan cenderung turun jika dilihat dari kondisi awal tahun ke akhir tahunnya (BRS Upah Buruh Desember, 2019).

Pada tabel 1, sebanyak $60,0 \%$ dari total 25 yang membahas mengenai pertumbuhan produksi dan manufaktur memiliki sentimen positif. Kemudian $16,0 \%$ memiliki sentimen negatif dan sisanya sebanyak $24,0 \%$ memiliki sentimen netral. Dominasi sentimen positif yang terjadi sejalan dengan fakta angka statistik bahwa pertumbuhan produksi dan manufaktur selama periode Triwulan IV 2018 sampai Triwulan III 2019 yang dirilis sepanjang tahun 2019 selalu mengalami kenaikan y-on-y terhadap periode Triwulan IV 2017 sampai Triwulan III 2018 baik industri manufaktur besar dan sedang (IBS) maupun industri mikro dan kecil (IMK) (BRS Pertumbuhan Produksi Industri Manufaktur November, 2019).

Pada tabel 1, sebanyak $66,7 \%$ dari total 42 berita terkumpul yang membahas mengenai Indeks Pembangunan Manusia (IPM) memiliki sentimen positif. Kemudian 14,3\% memiliki sentimen negatif dan sisanya sebanyak 19,0\% memiliki sentimen netral. Dominasi sentimen positif sejalan dengan fakta bahwa nilai IPM mengalami kenaikan pada tahun 2018 menjadi 71,39 yang sebelumnya pada tahun 2017 bernilai 70,81 atau dengan kata lain meningkat sebesar 0,58 poin atau tumbuh sebesar 0,82 persen (BRS IPM April, 2019).

Pada tabel 1, sebanyak $54,2 \%$ dari total 24 berita terkumpul yang membahas mengenai gini ratio memiliki sentimen positif. Kemudian $12,5 \%$ memiliki sentimen negatif dan sisanya sebanyak 33,3\% memiliki sentimen netral. Dominasi sentimen positif yang terjadi sejalan dengan fakta bahwa semenjak Maret 2015 hingga Maret 2019 nilai gini ratio terus menurun. Kondisi ini menunjukkan bahwa selama periode Maret 2015-Maret 2019 terjadi perbaikan pemerataan pengeluaran di Indonesia (BRS Gini Ratio Juli, 2019).

Pada tabel 1, sebanyak $100,0 \%$ dari total 1 berita terkumpul yang membahas mengenai Indeks TIK memiliki sentimen positif. Tidak ditemukan entitas person pada berita yang ada. Hasil sentimen yang bernilai positif sejalan dengan fakta bahwa terjadi peningkata Indeks TIK pada tahun 2018 menjadi 5,07 dibanding tahun 2017 yang bernilai 4,96 (BRS IP-TIK November, 2019).

Pada tabel 1, sebanyak 50,0\% dari total 8 berita terkumpul yang membahas mengenai inflasi memiliki sentimen positif. Kemudian $12,5 \%$ memiliki sentimen negatif dan sisanya sebanyak $37,5 \%$ memiliki sentimen netral. Dominasi sentimen positif yang terjadi sejalan dengan fakta bahwa nilai indeks demokrasi Indonesia (IDI) tahun 2018 mengalami kenaikan menjadi 72,39 dalam skala 0-100 terhadap nilai IDI tahun 2017 (BRS IDI Juli, 2019). Dengan nilai IDI yang meningkat mengindikasikan bahwa perilaku masyarakat Indonesia cenderung membaik dalam aspek demokrasi. Hal ini berkontribusi terhadap hasil sentimen yang bernilai positif.

Berdasarkan gambar 5, jika kita melakukan akumulasi terhadap hasil ekstraksi entitas Person maka didapat bahwa secara keseluruhan dalam berita yang dianalisis, berikut tokoh - tokoh yang berperan dalam memberikan informasi terkait poin - poin yang ada pada senarai rencana terbit BRS 2019 :

1. Suhariyanto (473 kali), Kepala Badan Pusat Statistik RI

2. Jokowi (263 kali), Presiden Republik Indonesia

3. Amran (215 kali), Menteri Pertanian

4. Darmin Nasution (174 kali), Menko Bidang Perekonomian

5. Sri Mulyani (114 kali), Menteri Keuangan 


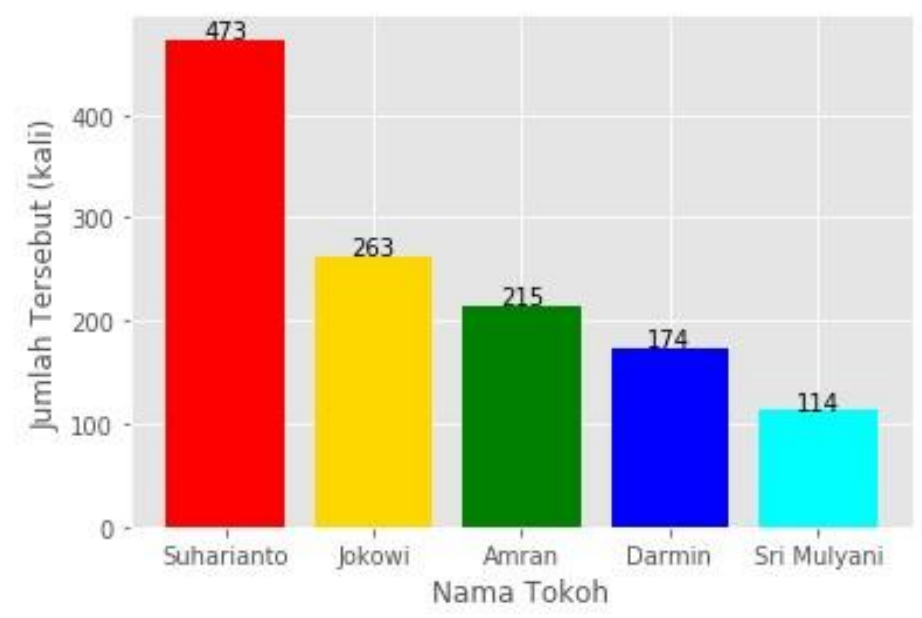

Gambar 5. Bar chart hasil ekstraksi entitas Person

\section{KESIMPULAN}

Bab Berdasarkan hasil penelitian di atas, maka dapat disimpulkan bahwa:

1. Berita dapat digunakan sebagai bahan analisis untuk melakukan penilaian terhadap opini yang beredar di masyarakat, dikarenakan hasilnya yang cukup relevan dengan keadaan aslinya.

2. Hasil sentiment analysis menunjukkan bahwa opini yang beredar di masyarakat mengenai angka - angka statistik sudah cukup baik, jika dilihat hasil sentimennya untuk tiap poin yang bersesuaian pada senarai rencana terbit BRS 2019.

\section{DAFTAR PUSTAKA}

Badan Pusat Statistik, 2019. Berita Resmi Statistik: Indeks Demokrasi Indonesia (IDI) 2018. Jakarta Pusat: Badan Pusat Statistik.

2019. Berita Resmi Statistik: Indeks Pembanagunan Manusia (IPM) Tahun 2018. Jakarta Pusat: Badan Pusat Statistik.

2019. Berita Resmi Statistik: Indeks Pembangunan Teknologi, Informasi, dan Komunikasi (ICT Development Index) 2018. Jakarta Pusat: Badan Pusat Statistik. 2019. Berita Resmi Statistik: Indeks Perilaku Anti Korupsi (IPAK) Tahun 2019. Jakarta Pusat: Badan Pusat Statistik.

2019. Berita Resmi Statistik: Indeks Tendensi Bisnis dan Indeks Tendnesi Konumen Triwulan III2019 serta Perkiraan Triwulan IV-2019. Jakarta Pusat: Badan Pusat Statistik. 2019. Berita Resmi Statistik: Perkembangan Indeks Harga Konsumen/Inflasi. Jakarta Pusat: Badan Pusat Statistik.

, 2019. Berita Resmi Statistik: Perkembangan Upah Pekerja/Buruh November 2019. Jakarta Pusat: Badan Pusat Statistik.

2019. Berita Resmi Statistik: Pertumbuhan Ekonomi Indonesia Triwulan III-2019. Jakarta Pusat: Badan Pusat Statistik..

, 2019. Berita Resmi Statistik: Pertumbuhan Produksi Industri Manufaktur Triwulan III-2019. Jakarta Pusat: Badan Pusat Statistik.

2019. Berita Resmi Statistik: Profil Kemiskinan di Indonesia Maret 2019. Jakarta Pusat: Badan Pusat Statistik.

2019. Berita Resmi Statistik: Tingkat Ketimpangan Pengeluaran Penduduk Indonesia Maret 2019. Jakarta Pusat: Badan Pusat Statistik.

Elfindri, E. (2011). Beberapa Teknik Monitoring dan Evaluasi (MONEV). Jurnal Kesehatan Komunitas, 1(3), 106-128. 
Hidayat, T. W. (2016). Analisis Berita Kesehatan di Media Massa terhadap Pelayanan Publik. JURNAL SIMBOLIKA: Research and Learning in Communication Study, 1(2).Agresti, A. (2000). Categorical Data Analysis (2nd ed). New York: John Wiley \& Sons.

Liu, B., Hu, M., \& Cheng, J. (2005, May). Opinion observer: analyzing and comparing opinions on the web. In Proceedings of the 14th international conference on World Wide Web (pp. 342-351). ACM.

Liu, B. (2012). Sentiment analysis and opinion mining. Synthesis lectures on human language technologies, $5(1), 1-167$.

Nurhuda, F., Sihwi, S. W., Doewes A. (2013), Analisis Sentimen Masyarakat terhadap Calon Presiden Indonesia 2014 berdasarkan Opini dari Twitter Menggunakan Metode Naive Bayes Classifier. Surakarta: Universitas Sebelas Maret.

Wahid, D. H., \& Azhari, S. N. (2016). Peringkasan Sentimen Esktraktif di Twitter Menggunakan Hybrid TFIDF dan Cosine Similarity. IJCCS (Indonesian Journal of Computing and Cybernetics Systems), 10(2), 207-218 